\title{
Subsidies, Spillovers and WTO Rules in a Value-chain World
}

\section{Bernard Hoekman}

\section{Robert Schuman Centre for Advanced Studies, European University Institute in Florence}

\section{Abstract}

As tariffs have fallen, subsidies and related policies with similar effect are being used to support local production. This raises the question of whether the existing World Trade Organization (WTO) 'rules of the game' are adequate. Assessing the economic effects of subsidies is complicated, given the need to consider linkages within and across supply-chain networks. Many of the policies that affect supply-chain operations are not considered subsidies under the WTO. There are no rules on subsidies for services or investment incentives by local governments. Conversely, some WTO rules may not be appropriate or effective given the increasing prevalence of global value chains. The widespread use of subsidies post-2008 suggests WTO members should launch a process of deliberation to revisit the status quo set of multilateral rules on subsidies. The 2015 Nairobi WTO ministerial declaration has created the necessary window to permit interested countries to do so. A central element of this should involve a concerted effort to collect better data and to analyze how subsidies and policies with equivalent effect impact on value chains, whether negative international spillovers are created and, if so, their magnitude and incidence.

\section{Policy Implications}

- Value-chain-based production and trade are changing the incentives of governments to use different trade policy instruments.

- WTO rules on subsidies need to be revisited as a result of the rising role of global value chains.

- More policy attention and resources must be devoted to international data collection and monitoring of the use of subsidy policies.

- Too much attention is being given to traditional trade-policy instruments like tariffs and antidumping - and too little to the use of different types of subsidies and measures with equivalent effect.

- Policies targeting trade in services and investment are not subject to multilateral disciplines even though these are likely to have negative impacts globally on welfare and efficiency.

\section{Trade policy post-2008 crisis}

The use of subsidies by governments expanded dramatically after the 2008 financial crisis, with many governments bailing out their financial sectors and providing subsidies to support certain manufacturing activities, most notably and visibly the automotive sector. While a direct response to a major financial/demand shock, the use of subsidy instruments - broadly defined to include fiscal measures such as tax exemptions and investment incentives such as tax holidays for new investment in a region - has been a constant feature of government policy in both high-income and emerging economies. This takes different forms in different countries, depending in part on fiscal and administrative capacity. A common feature is that intervention is often non-transparent.

Motivations underlying efforts to promote certain types of economic activity in a jurisdiction include a desire to generate employment and investments that are deemed desirable from an economic growth and development perspective. These often include 'high-tech'- and 'green-tech'-oriented activities, and more generally a desire to 'move up' the value chain (VC) by encouraging investment in innovation or activities that generate higher productivity and thus higher-paying jobs. The employment objective is often central in assistance programs targeting small and mediumsized enterprises (SMEs), the main source of employment in most countries. Examples of frequently used policies include government procurement policies; for example, giving price preferences to local firms or to firms that generate the highest local content, and locational investment tax/subsidy instruments. Frequently used examples of the latter are long tax holidays, financial guarantees or provision of services at below market rates.

Developments in the global trade landscape are discussed briefly in the next section, with particular focus on the emergence of international production networks and VCs, and the associated increase in the share of trade in intermediate products and services. I then provide a snapshot of recently compiled data on the use of various kinds of subsidies by governments following the 2008 financial crisis. These illustrate that subsidies are widely used, mostly by 
richer countries, and relatively more frequently for services than for goods. My analysis then turns to extant multilateral rules in the WTO for subsidies - the Agreement on Subsidies and Countervailing Measures (ASCM) - and discusses their salience for a world in which VC-based production accounts for an increasing share of global trade. The focus is on the WTO because (with the notable exception of the EU) most preferential trade agreements (PTAs) do little to discipline the use of subsidies. Very little is known regarding the motivations for the use of subsidies or the magnitude and incidence of negative spillovers created by subsidy policies. Matters are complex because it is necessary to take into account the linkages within and across VC networks. Determining the net effects of sectoral or firm-specific government policies is more complicated than in a world where trade is based on countries or industries specializing according to comparative advantage. In a VC world, there may be efficiency reasons for governments to intervene in a targeted or specific manner - for example, to address coordination failures - and such interventions may benefit foreign plants or firms, their workers and local communities. Negative spillovers can and will occur, as will deadweight losses, but their incidence may be unclear ex ante, making it difficult to assess or identify rules of thumb for possible multilateral disciplines.

The economic rationale for the multilateral subsidy rules embedded in the WTO has been challenged by scholars using analytical frameworks that do not consider global VCs (e.g. Sykes, 2010). Whatever one's views on this question, the greater complexity of international production that is associated with VCs implies that many of the elements of the ASCM may need to be revisited. The final section argues that the many open questions pertaining to the use and effects of subsidies suggest that WTO members consider engaging in a 'discovery process' - putting in place mechanisms that provide firms and governments with a forum in which to discuss the effects of nontariff policies on investment decisions and the operation of VCs. A precondition for determining whether new disciplines are needed in the area of subsidies, broadly defined, is better information and much more empirical research on the magnitude and incidence of negative international spillovers that are created by prevailing policies.

\section{The rise of VCs in international trade}

Trade patterns and paradigms have shifted in recent years, with increasing fragmentation of global production along VCs. An international VC involves a collection of firms (plants) located in different countries jointly forming a 'production line', with different parts of the production process undertaken by firms (plants) in different countries. Depending on the location of a firm (country) in a VC/production network, participation may either involve forward linkages (where an activity produces an output that is used in production for export to another nation) or backward linkages (where a firm uses imported parts and components that are inputs for production that is exported). An example is a country $A$ that produces hides from cattle that are tanned and dyed in a neighboring country $B$ using chemicals imported from a third country $C$, with the leather produced in $B$ used in the production of a car seat cover in country $D$ that is shipped to a car plant located in country $E$ that exports the cars to country $F$.

A VC permits enterprises in different countries to concentrate on (specialize in) specific tasks and activities without having to source required inputs locally or integrating vertically to produce and market the end product. A VC increases interdependence: each link in a chain relies on the upstream producers delivering their output on time and meeting the required quality and safety standards; upstream firms are dependent on the downstream segments working efficiently, as stoppages or distribution problems there will affect the demand for inputs. The supply chain trade (SCT) associated with outsourcing and investment location decisions by large manufacturing and retailers (so-called lead firms) is often predominantly regional in nature (i.e. centered on Europe, North America and East Asia), although most VCs will embody at least some content that is produced outside the region.

The growth in SCT has been supported by - indeed, is dependent on - cross-border movement of capital and knowledge (as the technology and know-how needed to undertake the various activities is often firm-specific). The increase in VC production is highly correlated with an expansion in foreign direct investment (FDI) (UNCTAD, 2013). The global value of the stock of FDI increased more than sixfold in the last decade or so; local sales by foreignowned firms were some US\$26 trillion in 2012, compared to US\$18 trillion for world merchandise trade.

Companies are the drivers of trade of international commerce. It is firms that invest and create the employment needed to undertake production activities and 'do trade' ranging from smallholder farmers, to microenterprises and SMEs that provide a variety of inputs, to logistics providers, processors, manufacturers and service suppliers. SCT is dominated by large multinational companies or lead firms that decide where to locate plants, where to invest, who to source from, and so on. Some 80 per cent of world trade is estimated to involve multinational companies (UNCTAD, 2013). All of these firms source inputs and buy services from local suppliers and subcontractors. As a result, much SCT is 'indirect': the value of a final good incorporates payments for many intermediate goods and services that are not exported directly. Thus, a wide range of firms and sectors, including companies providing services to firms in other sectors, benefit from and are affected by VC-based trade and investment opportunities. Available data indicate that about one third of the value of all traded manufactured goods reflect the value of embodied services, and that, overall, if account is taken of sales of services by foreign affiliates, services account for more than 50 per cent of world trade (Francois and Hoekman, 2010).

One result of the increase in SCT is that imports make up an increasing share of the total value embodied in a given product: ranging from 25 per cent to 40 per cent or more 
for small open economies that are integrated into supply chains (OECD, 2013). SCT can be broken down into imports of inputs that are used in the production of exports ('backward linkages') and exports of intermediates that are processed in the importing nation and then exported to a third country ('forward linkages'). The relative magnitude of each of these types of trade varies significantly across countries, as does the overall share of supply-chain networks in total trade. The differences reflect a number of factors, including economic size, level of development, location and policy. Countries that are far away from centers of economic demand and activity will also have lower participation in supply chains because of relatively high transport costs. If a country imposes high trade barriers or pursues industrial policies that make it difficult and more costly to import parts or components, investors may decline to invest there.

The structure and volume of SCT is very sensitive to trade and other transaction costs - both direct financial and operating costs, and costs associated with the management of the associated networks. Reliability and predictability of flows of goods and services within the relevant networks is critical. Uncertainty and risks of incurring delays associated with unpredictable operating environments give rise to a need to maintain higher stocks and other forms of hedging and insurance, the costs of which may preclude SCT investments. Differences in the operating environment do much to explain why VC investment and production tend to be regionally concentrated, and why SCT in most of Africa and much of Latin America and South Asia is limited compared to North America, Europe and East Asia.

Policy in a supply-chain world is more complex than in one where trade is of a 'ship and forget' nature and traded products are produced using local factors of production and locally produced inputs. An open trade regime becomes more important, as does action to minimize trade frictions such as delays in border clearance, low-quality transport and logistics that lead to physical losses, and difficulties in investing in operating or distribution facilities. Connectivity including the quality of transport and logistics services, information and communications technology (ICT) networks and related services - is a critical determinant of competitiveness. Particularly relevant for the subject of this article is that the policy agenda is about more than reducing trade costs. There may be a need for specific types of government intervention to address coordination failures. Subsidies may be part of the set of instruments that can be used to address VC-specific market failures.

\section{Potential rationales for government intervention}

The set of policies that can act to promote an economic activity is very large. Any measure by a government to disadvantage one activity relative to another will have the effect of subsidizing the latter. It is therefore necessary to recognize that if one seeks to discipline subsidies that give rise to negative international spillovers, the focus of attention must go beyond narrowly defined fiscal transfers. In the WTO context, an actionable subsidy is a measure that imposes a burden on the budget, is specific to an activity (as opposed to benefiting economic activity more generally) and conveys a benefit to those targeted. Subsidies that have an economy-wide impact and are not specific (education, general infrastructure, and basic research and development) are not actionable. Specific subsidies might include support for exports or local content requirements (reducing incentives to import); targeted financial support, such as grants or loans from publicly capitalized banks; fiscal incentives such as grants or preferential financing to 'encourage' industries into expand higher-technology exports; tax incentives that promote particular activities or technologies; investments in supporting economic infrastructure; aid schemes for SMEs; export credit insurance; state aid for in the form of loan guarantees for specific products; ad hoc rescue and restructuring aid, and so on. From an economic perspective, notwithstanding that this is a rather long list of measures, any policy that has differential effects across sectors or activities will act as a tax or subsidy, suggesting that any list of subsidies will be incomplete.

Subsidies that are sector-specific may have an economywide objective. Examples include subsidies to sectors such as health, education, transportation and communications. Conversely, subsidies that are economy-wide in scope may effectively be industry-specific; for example, the pursuit of an environmental objective whose attainment requires taxes or subsidies that primarily affect specific sectors such as the chemical or automotive industries. It may well be that other policies maintained by the government outweigh any direct support given to a firm or sector. Such general equilibrium measures of the net or 'effective' support that is implied by policy is important in assessing impacts on firms and on the rest of the world. What matters then is the effect of all policies taken together: do they stimulate or support a specific activity? If so, what matters from a rule-making perspective is whether they have a significant negative welfare impact on other countries and/or the world as a whole.

Subsidies are used for many reasons. They may be motivated by economic (efficiency) or non-economic goals (for example, to redistribute income in an effort to improve the equity of outcomes, or to buy political support or to create rents for politically well-connected individuals or groups. Policies that reflect rent seeking or rent creation will usually be market-distorting if they affect production. Policies that reflect economic objectives may or may not be market-distorting. A basic efficiency rationale for tax-subsidy schemes is to bring marginal private costs or benefits into alignment with marginal social costs or benefits. The need for this arises when externalities (market failures) cause social and private costs and benefits to diverge, so that private agents are not given an incentive to take into account the costs or benefits of their actions on others in the economy. Necessary conditions for a more efficient allocation of resources to result from intervention are that the problem is diagnosed correctly and the policy is targeted appropriately. In practice governments can easily fail of these tests, especially if account is taken of the incentives of interest groups to lobby for a subsidy or a tax exemption. 


\section{VCs and subsidy-like policies}

Theoretical or empirical research on subsidies within a VC environment is very sparse. The limited extant literature tends to focus on trade policy (tariffs) not subsidies, with the exception of investment and location subsidies. The policy literature has noted that vertical specialization changes the incentive structure confronting firms and thus governments. The expansion of SCT, in conjunction with the associated flows of FDI, is expected to attenuate the incentives to use traditional trade policy instruments like tariffs. Being able to compete in a specific niche or value-adding activity requires that firms integrate into the relevant production networks. Significant levels of import protection would impede their ability to do so as it would increase the cost of inputs. In a recent empirical analysis, Gawande et al. (2015) showed that the intensity of a country's vertical specialization helps explain observed trade policy responses to the 2008 crisis as well as the level of trade protection pre-crisis.

SCT may increase incentives for governments to use subsidies and subsidy-like instruments to target specific domestic economic activities. Analogous to tariffs and import protection, these may create negative international spillovers - for example, subsidies and similar policies to attract SCTlinked FDI that generates incentive competition between governments.

Baldwin and Venables (2015) provide a framework for analyzing the interaction of forward and backward linkages within and across supply chains. This is important for considering the effects and design of policy because inputs will usually enter into multiple supply chains (multiple sectors). Thus, services are used in the production of many different products, and vice versa: the final products produced by many VCs will require common inputs. ${ }^{1}$ They focus on the effects of different trade and industrial policy instruments and show that linkages across VCs create multiplier effects. For example, support for final-goods producers can increase the range of parts and intermediate inputs produced in a territory, broadening the industrial base and attracting the entry of further downstream goods producers. Policies that on the margin expand the range of upstream inputs that are produced are likely to generate more industrialization than policies that promote parts production within the margin (parts that are already produced domestically), or parts far beyond the margin (highly sophisticated parts that are not used in locally produced final goods but are all exported within a given VC).

Baldwin and Venables demonstrate that policies that support (subsidize) local production of intermediate inputs can result in an expansion of the industrial base. This includes incentives to attract VC FDI, with the impact on SCT participation depending on the range of available input production capabilities in the host country and whether policies targeting entry of FDI result in demand for locally produced inputs that allows the producers concerned to become competitive intra-VC suppliers (by allowing them to expand the scale of production). Policies that expand the range of parts and inputs (that is, the extensive margin) are more likely to result in expansion of the industrial base. However, as is the case in the strategic trade literature of the 1980s and 1990s, policy can easily get it wrong and result in adverse (welfarereducing) effects.

This is illustrated in a recent analysis of the effects of steel-sector industrial policy in major steel-producing countries from 1975 to 2000. Bloningen (2015) examines the impact of policies to support local steel production on the export competitiveness of downstream manufacturing sectors that are significant users of steel. He finds that a onestandard-deviation increase in the use of export subsidies and non-tariff barriers leads to a 3.6 per cent decline in export competitiveness for an average downstream manufacturing sector. But this negative effect can be as high as a 50 per cent decline for sectors that use steel as an input most intensively. Conversely, policies that target downstream activities may be to the detriment of upstream suppliers, especially if the former have market (monopsony) power - as is the case with automobiles, for example (Van Biesebroek and Sturgeon, 2010).

There has been extensive research on tax and subsidy policies targeting FDI, but most of this work does not consider production that is organized in multi-country VCs. ${ }^{2}$ The upshot of much of this 'non-VC' literature is that differences in tax regimes and FDI incentive schemes have an economic impact in that they are one factor explaining the allocation of FDI across jurisdictions. ${ }^{3}$ There are a number of possible efficiency (welfare-improving) rationales for FDI subsidy policies. These center around positive spillovers that are associated with FDI, with intervention justified either because of market failures or as a second-best instrument to create incentives for FDI in locations where this would have a high social return, including by generating positive agglomeration externalities. For example, Haufler and Mittermaier (2011) show that subsidies to FDI may give trade unions an incentive to exert wage restraint in exchange for additional jobs that are created in the newly attracted firms. A subsidy that more than compensates a firm for higher wage costs can not only induce a foreign investor to locate in the unionized country, but also generate the incentive for the union to choose to lower wages and get the FDI as opposed to a situation where wages are higher and employment is lower.

At the same time the literature also points to the potential for welfare-reducing subsidy competition between jurisdictions. For example, Ossa (2015) analyzes the effects of investment-related tax/subsidy incentives at the state level in the US. US states 'spend' some US\$80 billion a year on tax incentives and subsidies to investment, reflecting a vigorous competition to attract investment. Ossa finds that this competition increases state-level welfare (by attracting firms, increasing employment and raising wages) but generates beggar-thy-neighbor effects. While there are large potential gains at the state level from subsidizing investment, this distorts resource allocation by making intermediate inputs too cheap and generating excessive entry. There is a significant cost to the US as a whole: if states were to refrain from subsidy competition, manufacturing real income in the US as a whole would be 3.9 per cent higher. 
Although investment subsidies may be costly, they can generate the outcomes that are sought by governments, such as local employment. Criscuolo et al. (2012) estimate the impact of a 'regional selective assistance' program that offers investment subsidies to firms in depressed areas on condition they create or safeguard manufacturing jobs in these areas. Area eligibility is governed by EU state aid rules. Periodic changes in these rules allow the authors to construct instrumental variables for program participation and identify causality. Using two decades of UK panel data on the population of firms and matching these to program participants, Criscuolo et al. find positive effects on employment, investment and net entry. A 10 per cent investment subsidy generates about a 7 per cent increase in manufacturing employment (around 100,000 a year). The 'cost per job' was estimated at US\$6,300, suggesting that in some respects investment subsidies can be cost-effective. This illustrates the difficulty of achieving international (or intranational) cooperation; this would be easier to achieve if policies were ineffective.

Moran (2014) focuses on the available evidence on the role and effects of policies that target FDI using an SCT lens. Coordination failures, information asymmetries, missing inputs of both a general (cross-sectoral) and very specific nature that are critical to VC production and SCT, and uncertainty regarding the policy stance, goals and capacity of a government may all be prevalent in a country or jurisdiction and call for proactive policy. A central feature of such policy from an FDl-attraction perspective will be to address the constraints that impede FDI (entry, establishment) and that limit the extent to which investors create and grow backward linkages - that is, connect with local suppliers of inputs (both goods and services). VC opportunities and related spillovers provide another rationale for creating an environment that is attractive to FDI. In a VC world, investment promotion becomes particularly important and this may need to go beyond the provision of information, reducing uncertainty on the business environment and ensuring efficient trade facilitation. Targeting investment by first-tier suppliers of lead firms and contract manufacturers and providing support for the creation of back ward linkages are two examples of policies that can help expand national SCT trade and VC participation (Gereffi, 2014; Farole and Winkler, 2014). ${ }^{4}$

VCs differ from the standard context analyzed in the older trade and development literature as they involve (sets of) firms and plants in many countries. Instead of value added being mostly national, in a VC world the value of a final product is generated in many countries that are part of a network. Thus, interventions that expand the ability of a country to provide a greater share of total inputs may have both positive local spillover effects, and at the same time, assuming a government does so effectively and enhances the competitiveness of the VC as a whole, give rise to positive as well as negative cross-border spillovers (Van Biesebroeck, 2009). ${ }^{5}$ The direction and size (distribution) of spillover effects will depend on linkages across countries within a VC and linkages across chains - both competing
VCs and non-competing chains that may use the same type of inputs or that are buyers of what another VC produces.

The limited research literature suggests that although negative spillovers are very likely to be created by FDI incentives, governments seeking to expand national SCT participation can use policy to increase investment and employment. ${ }^{6}$ In that sense, there is nothing new about VCs as regards the potential benefits of cooperation on rules of the game. But such cooperation is likely to be harder to design, given that the distributional and efficiency effects are more difficult to determine ex ante and the potential greater scope or need for targeted interventions to address coordination failures that may impede FDI or SCT investments.

Investment incentives are likely to play a particularly important role in a VC context. These need not involve direct fiscal transfers. Even if they do, that will only be one element of the set of measures that may be needed if the goal is to address coordination and other market failures. VC-related interventions to address such failures may also need to be very specific. While this reduces the potential for white elephants, as discussed later, targeting also implies that specific policies that are welfare-enhancing may fall foul of WTO rules.

\section{Use of subsidies: a post-2008 snapshot}

Data on subsidies are notoriously patchy and incomplete. One very useful recent source of data on the use of subsidies and related policy instruments is the Global Trade Alert (GTA). What follows discusses the information that is reported in that database. No effort is made to assess the magnitude, let alone the effects of subsidies; the aim is simply to determine the relative intensity of the use of subsidies by looking at the number of subsidy measures imposed, how this varies across countries as a function of per-capita income, and the distribution of measures by broad sector of economic activity (goods vs services). It should be stressed that the approach used to do this is very rudimentary and purely exploratory. The GTA data only starts in 2009 and much of what is reported are policies put in place as a response to the financial crisis; we cannot compare with the 'steady-state' use of subsidies before the crisis. However, the same is true for the trade policy measures that are registered in the database. The relative importance of subsidies and measures with equivalent effect is most probably seriously underestimated in the data because the measures are not weighted by economic impact, and trade policy measures taken by the EU are counted separately for each EU member state. Thus, an antidumping duty imposed by the EU is counted 28 times, while a subsidy implemented by an EU member is counted only once. For these reasons, the share of subsidies in total measures is biased downward substantially.

Figure 1 and Table 1 report information on all traderelated measures that have been collected by the GTA as of April 2015. These spanned a total of 22,569 measures, ranging from tariffs and quotas to antidumping and investment 
Figure 1. Use of Different Measures, All Countries, 2009-2014 (\% share).

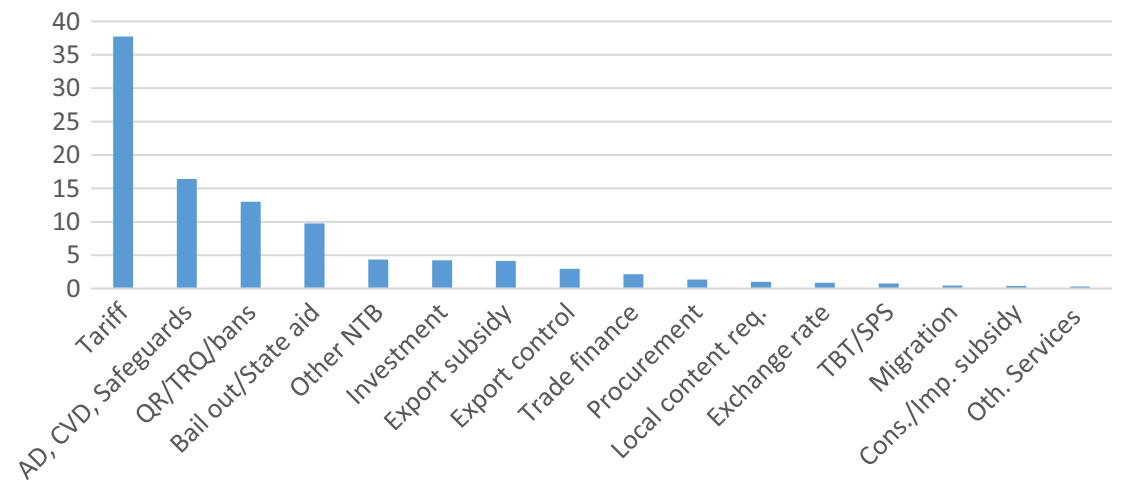

Source: GTA

Table 1. Number of subsidy measures by country group and shares, 2009-2014

\begin{tabular}{|c|c|c|c|c|c|c|}
\hline Country group & All & OECD & Other HIC & UMIC & LMIC & LIC \\
\hline State aid & 2205 & 1147 & 484 & 399 & 149 & 4 \\
\hline Consumption subsidy & 30 & 4 & 14 & 7 & 5 & 0 \\
\hline Export subsidy & 938 & 349 & 130 & 258 & 180 & 11 \\
\hline Import subsidy & 61 & 20 & 8 & 18 & 14 & 0 \\
\hline \multicolumn{7}{|l|}{ Shares (\%) } \\
\hline All subsidies (\% of total) & 14.3 & 15.9 & 21.8 & 11.1 & 10.6 & 4.7 \\
\hline Of which, export subsidies & 29.0 & 23.0 & 20.4 & 37.8 & 51.7 & 73.3 \\
\hline \multicolumn{7}{|l|}{ Other measures, number and share (\%) } \\
\hline Tariffs & $8518(37.7)$ & $3238(34.0)$ & $1087(37.3)$ & $2852(46.3)$ & $1037(31.5)$ & $153(47.8)$ \\
\hline TTBs & $3707(16.4)$ & $2126(22.3)$ & $424(14.6)$ & 779 (12.7) & $286(8.7)$ & $0(0.0)$ \\
\hline QR/TRQ/import bans & $2933(13.0)$ & $1807(19.0)$ & $411(14.1)$ & $486(7.9)$ & $133(4.0)$ & $13(4.1)$ \\
\hline Trade finance, procurement, LCRs, investment measures & $1978(8.8)$ & $440(4.6)$ & $172(5.9)$ & $493(8.0)$ & $814(24.8)$ & $59(18.4)$ \\
\hline
\end{tabular}

HIC, high-income countries; UMIC, upper-middle-income countries; LMIC, lower-middle-income countries; LIC, lower-income countries; TTB, temporary trade barriers; $Q R$, quantitative import restrictions; $T R Q$, tariff rate quota; $L C R s$, local content requirements.

Source: GTA, March 2015.

incentives. Tariffs and contingent protection ('trade remedies' or 'temporary barriers to trade' - antidumping, measures to countervail the effects of subsidies and safeguards) account for two thirds (67 per cent) of all measures imposed. Four subsidy categories are distinguished in the GTA database (state aids, consumption subsidies, export subsidies and import subsidies). Taken together, these accounted for 14.3 per cent of all measures imposed (for a total of 3,234 measures), the third most frequently used policy instrument in the post-2008 period. For high-income, non-Organization for Economic Cooperation and Development $(\mathrm{OECD})$ countries, subsidies are the second most frequently used instrument after tariff measures. ${ }^{8}$

Almost one third (29 per cent) of the subsidies used target exports (Table 1). Not surprisingly, high-income countries make more use of subsidies than lower-income economies. Subsidies account for 21.8 per cent of all measures imposed by rich countries that are not a member of the $O E C D$, whereas they account for only 5 per cent of the measures used by low-income countries. Although subsidies account for 10 per cent or less of all measures imposed by developing countries, the share of export subsidies rises as per-capita incomes decline, suggesting that poor developing countries are more focused on directly promoting export competitiveness. Investment measures account for only 4.2 per cent of all measures for the sample as a whole, but account for around 12 per cent of all measures imposed by lower-middle-income and low-income countries. ${ }^{9}$ Taken together, measures to provide trade finance, allocate procurement to domestic firms, local content requirements and investment policy actions account for 24.8 and 18.4 per cent of all measures taken by lower-middle-income and lowincome countries, respectively - a much higher proportion of all measures than is observed in richer countries.

Not surprisingly (given that services cannot be affected by tariffs or temporary trade restrictions like antidumping), subsidies and other 'non-border' measures are used more intensively for services. For the sample as a whole, subsidies account for about one third of all measures pertaining to services. Investment measures account for another third. The biggest difference in instrument use between the goods and services sectors is for investment measures. ${ }^{10}$ Here again, high-income countries, both OECD and non-OECD, make the most intensive use of subsidies: around 50 per cent of all measures targeting services are subsidies. Lowerincome countries, in contrast, rely primarily on investment 
measures, which account for more than 60 per cent of all measures used in lower-middle-income and low-income countries targeting service sectors.

The data that have been discussed pertain to the use of different instruments. In practice the policy action that is involved may have the effect of reducing or increasing trade. The GTA includes a code that reflects the assessment of the compilers of the database as to whether the measure restrains or expands trade, or the effect is ambiguous. These assessments are based on first principles, not on an analysis of estimated effects. Thus, a reduction in a tariff is regarded as liberalizing (coded 'green' in the GTA), whereas an increase in a tariff would be coded as 'red'. For some instruments virtually all measures are trade-restrictive. This is the case for antidumping and other temporary trade barriers, for example. There are interesting differences in the 'direction' of policy across instruments and country groups. For tariffs, many of the actions taken by high-income countries and upper-middle-income countries involve liberalization some 70 per cent or more of all observations. This is also the case for quotas and tariff rate quotas. In contrast lowermiddle-income countries tend to be more restrictive, with more than 50 per cent of observations coded red.

As far as state aid and investment measures are concerned, the aim of policy is on average more trade-restrictive or discriminatory than is the case for traditional trade policies (abstracting from antidumping and other contingent trade policies). Some 70 per cent of subsidy measures taken by richer countries are discriminatory; for lower-middleincome countries the share is 100 per cent. In contrast, investment measures taken by lower-income developing countries are much more weighted towards reducing discrimination against foreign firms, while in OECD countries and upper-middle-income nations there is rough balance between liberalizing and more discrimination. As far as services are concerned, subsidies are almost all coded red, i.e. they involve discrimination in favor of local firms, whereas investment measures in developing nations are biased towards liberalization. This is not the case for OECD countries, where a significant share of investment-policy measures involves an increase in discrimination or restrictiveness.

\section{Implications for current WTO rules}

WTO disciplines relating to subsidies on goods have a twofold objective. First, to establish rules to avoid or reduce adverse effects on members and, more specifically, to prevent the use of subsidies to nullify or impair concessions. Second, to regulate the use of countervailing duties (CVDs) by members seeking to offset the injurious effects of foreign subsidization of products on their domestic firms. Adverse effects include injury to a domestic industry, nullification or impairment of tariff concessions, or serious prejudice to the country's interests. Serious prejudice is defined to exist if the total ad valorem subsidization of a product exceeds 5 per cent; subsidies are used to cover the operating losses of a firm or industry; or debt relief is granted for government- held liabilities. Serious prejudice may arise if the subsidy reduces the exports of WTO members, results in significant price undercutting or increases the world market share of the subsidizing country in a primary product. The focus of WTO disciplines in cases of prejudice is on the amount of the assistance given, not on the extent to which a subsidy harms trading partners. The General Agreement on Trade in Services (GATS) has no subsidy disciplines for services. While basic disciplines such as the most-favored-nation rule and national treatment may apply to specific service sectors if these are scheduled, in practice subsidy measures are likely to be carved out through a 'limitation on national treatment'.

The ASCM is premised on trade involving goods that are produced in one country and sold to another, i.e. implicitly if not explicitly (most) value added is assumed to be generated from domestic factors of production. This is not the case for VC-based SCT. As a result, it is less clear who benefits from a 'subsidy'. Is it the VC as a whole, with the impact reflected in the final good? Or is the impact on specific segments only? Given the potential substitutability and/or complementarity of policy instruments, it becomes necessary to consider a broader set of policies and whether these as a whole generate negative spillovers - most notably investment incentives. In any such assessment, the first order of business is to identify and define the spillovers that are of concern.

WTO rules require a finding that a domestic industry is being injured by a foreign subsidy before a CVD can be imposed. VCs involve complex relationships between the links in the chain or nodes of the network that ensure reliability of supply, quality, interconnection and so on. Therefore, domestic-input suppliers that are not part of a VC that imports parts or components may not benefit from taking action against subsidized imported inputs used by a VC. The end result may simply be that the relevant lead firm simply absorbs the cost of a CVD or else moves production elsewhere. $^{11}$

As FDI policy is an important aspect of VC or SCT-related policies, an issue from a WTO perspective is that local incentives to attract investment are not covered by WTO rules. The focus of WTO subsidy rules is on whether interventions are export subsidies, or cause adverse effects for exporters in third markets or domestic import-competing producers. But if the main goal and effect of SCT-promoting policies is to attract or retain $\mathrm{FDI}$, the issue becomes one of investment diversion and global efficiency; cooperation aimed at preventing inefficient competition between jurisdictions that simply generates rent transfers to investors as opposed to addressing a market failure.

An implication of the centrality of FDI and more generally of investment for VCs is that discrimination (violating national treatment) may be less of an inherent feature than it is for trade policy. Governments may care less about the nationality of owners of plants than they do about local employment. The spillovers that may arise are therefore somewhat different from those motivating many WTO rules - a concern about the effects of policy on exporters. If the 
policy at hand in an investment incentive, effects are not (only) on exporters but on locations for investment; that is, the potential problem is investment diversion. Non-discriminatory investment policies may be distorting by attracting investment to less efficient locations. Thus, if countries want to level the playing field, governments will need to sit down and negotiate rules on investment incentives. Given the importance of services as a source of value added and in driving VCs, any such effort should span all sectors and include a focus on subsidies for services.

This will be a very difficult exercise, however, as it must go beyond subsidies in the narrow sense of a fiscal transfer as defined in the ASCM and span a broader set of policies, including investment incentives. Given the complexity of determining the distributional effects of VC or SCT policy interventions, the challenge of agreeing on rules ex ante will include defining what constitutes an undesirable spillover and an assessment of the potential that different measures will have to generate such spillovers.

The research discussed previously points to the existence of negative spillovers and suggests a case for international disciplines. But it is very much an open question whether countries will agree that rules should be pursued. In the WTO working group on investment, it became clear early on that major OECD governments were not willing to discuss investment incentive programs, removing much of the potential rationale for a multilateral agreement (Hoekman and Saggi, 2000). In a VC context, there may be even less appetite to agree to disciplines, given that the high import content of any given VC means investment subsidies will benefit foreign interests as well as local ones. While there may well be investment diversion, documenting this is not straightforward given the overall distorted operating environment that is likely to reduce investment below what it otherwise would be in many lower-income countries.

Matters are complicated further by the fact that SCT subsides will be embedded in products - that is, the impact on the end product is indirect and depends on the value share of the subsidized activity in the total. The extent to which services inputs and contributions to a VC benefit from government support will need to be considered (on average, services account for one third or more of the value of goods) (OECD, 2013). Thus, to measure the effect of interventions, an analysis is needed of the sources of value added or profits. The size of the subsidy per se is not the right focus. In addition, the notion of injury would need to be revisited: given that a VC comprises a range of firms in different countries, does it make sense to allow a firm (a set of firms) that are not part of given VC to take action that is aimed at inducing a lead firm to source from them as opposed to the preferred suppliers if the action simply makes the end product(s) less competitive on world markets, and may well induce the lead firm to pack up and leave? From an FDl-attraction perspective, permitting firms to launch CVD actions is likely to run counter to investmentpromotion objectives and have detrimental impacts on the reputation of a country as a platform for VC-based activity.

\section{Conclusions}

A consequence of VC trade is that policy becomes more complex to design and the impacts of subsidy policies are more difficult to assess than in a world where trade does not involve vertical specialization and unbundling of production activities across many locations. The trope that further research and analysis is required applies here with a vengeance. A precondition for such analysis is much better data on applied policies. Current data collection and reporting effects are biased towards a subset of trade policy instruments; the coverage and quality of data on subsidies and investment measures/incentives is much lower than for traditional trade policies such as tariffs and 'temporary' trade barriers.

Given interdependencies and linkages between the various activities that are part and parcel of VCs, there may be greater need for proactive policies. Many of these are the well-known horizontal policies that center on the investment climate, property rights, rule of law, skills, infrastructure, connectivity and so on. However, specific interventions may be needed as well, targeting coordination failures and missing links. The policy mix may include investment incentives of a fiscal nature, which may be efficient and/or politically rational from a local perspective of attracting firms and generating employment. But other policy measures that have similar effects - including generating negative spillovers on other countries and potential investment locations - may be preferred by governments over narrowly defined subsidies. An example are tax concessions or credit guarantees offered by municipal or provincial governments to foreign investors, where there is extensive evidence that excessive competition between governments reduces aggregate welfare. Thus, in so far as countries can agree that there are joint benefits to be had from cooperating on rules of the game in this area, they will need to go beyond subsidies as defined in the WTO.

At present, the ASCM does not cover services and thus misses a large part of what drives VCs and the value addition that occurs along a VC. It also does not cover FDI subsidies. Nor does it address regulatory policies that may be used to discriminate in favor of domestic economic activity. The prevalence of VCs calls for policy analysis and international cooperation to focus more on policies' overall impact on VCs. The main need at this point, however, is not to start from the premise that new rules need to be negotiated, but instead to determine how existing ASCM and other WTO disciplines impact on SCT and whether there are significant negative spillovers stemming from national policies, including measures put in place by sub-central governments. The opening created by the 2015 Nairobi WTO ministerial conference for WTO members to discuss both old and new issues outside the framework and modalities established by the Doha Development Agenda offers a good opportunity to launch a discussion about whether changes should be made in the multilateral disciplines that apply to subsidies and related policies. 
A necessary condition for any such determination is much better data on the policies that are used by governments around the world, both at the central and sub-central levels. That will require a shift in prioritization of the transparency and monitoring efforts of international organizations, including a concerted effort to map tax or subsidy policies that affect or target FDI and service-sector activities. This will be challenging given that WTO members have a poor record in terms of reporting subsidy measures. The poor track record suggests that greater support should be given to independent efforts such as the GTA to collect and report data on subsidies and related policy instruments.

\section{Notes}

I am grateful to an anonymous referee and to the editor for their helpful comments on an earlier draft, to Matteo Fiorini for putting together the GTA data and Johannes Fritz for his assistance in making the data available.

1. The economic literature on outsourcing, offshoring and trade in tasks tends to limit attention to the unbundling of production processes within an industry across multiple countries or locations, not on cross-industry or cross-VC interactions that generate potential spillovers as well as interdependencies.

2. See Blomstrom and Kokko (2003) for a review of much of the literature.

3. In a recent comprehensive study of the drivers of FDI stocks, Bloningen and Piger (2014) conclude that most host-country businessenvironment variables, including host-country infrastructure and institutions, are not robust determinants of FDI. However, while they consider the effects of trade and bilateral investment agreements, they do not assess the importance of investment incentives.

4. The general literature on FDI already provides extensive evidence of its positive effects (in both the goods and services sectors) on total factor productivity (TFP), wages and so on. See, for example, Moran (2014).

5. McGuire (2014) documents how some countries have used selective government intervention to help national firms accumulate the expertise and experience needed to build a niche in specific segments of the international global aerospace VC, based in part on collaboration with global players in the industry.

6. Subsidies may be a second-best device for governments to overcome constraints that impede investment that they cannot affect. An example of such a constraint is trade policy. A local government cannot affect a nation's trade policy, but this may be very important from a VC or SCT perspective. Kimmitt and Slaughter (2015) note that the limited number of PTAs negotiated by the US meant that Audi set up a plant in Mexico instead of Tennessee, in part because Mexico offered a location that had duty-free access to some 40 countries with which it had PTAs. In a VC world, what matters is access to inputs and getting processed or final products into export markets duty-free. Investment incentives are a potential instrument that a local government can use to offset specific locational or operating disadvantages but as this example illustrates, that may not be sufficient.

7. See the GTA website, www.globaltradealert.org.

8. Note again that the focus here is on a simple 'count' of measures, not on the value of the support granted or their effects. Given that state aids during this period were often very large in value terms, the implied share of subsidies vs other policies is a downwardbiased measure of the economic significance of this instrument.

9. Table 1 provides data on all measures reported in the GTA database. Investment measures include tax or subsidies for FDI and policies affecting the ability of foreign firms to establish a commercial presence.
10. In interpreting these data it should be recognized that services account for only a small share of total measures covered by the GTA database ( 6 per cent). The main focus of trade policy is, not surprisingly, on goods.

11. Issues of transfer pricing will arise in assessing the extent to which a subsidy has benefited a given activity or the VC as a whole (the price or cost of the final good).

\section{References}

Baldwin, R. and Venables, A. (2015) 'Trade Policy and Industrialization: when Backward and Forward Linkages Matter', Research in Economics (in press).

Blomström, M. and Kokko, A. (2003) The Economics of Foreign Direct Investment Incentives. Cambridge, MA: NBER Working Paper 9489.

Bloningen, B. (2015) 'Industrial Policy and Downstream Export Performance', Economic Journal [online], DOI: 10.1111/ecoj.12223.

Bloningen, B. and Piger, J. (2014) 'Determinants of Foreign Direct Investment', Canadian Journal of Economics, 47(3), 775-812.

Criscuolo, C., Martin, R., Overman, H. and Van Reenen, J. (2012) The Causal Effects of an Industrial Policy. Cambridge, MA: NBER Working Paper 17842.

Farole, T. and Winkler, D. (eds.) (2014) Making Foreign Direct Investment Work for Sub-Saharan Africa: Local Spillovers and Competitiveness in Global Value Chains. Washington, DC: World Bank.

Francois, J. and Hoekman, B. (2010) 'Services Trade and Policy', Journal of Economic Literature, 48(3), 642-692.

Gawande, K., Hoekman, B. and Cui, Y. (2015) 'Global Supply Chains and Trade Policy Responses to the 2008 Financial Crisis', World Bank Economic Review, 29(1), 102-128.

Gereffi, G. (2014) 'A GVC Perspective on Industrial Policy and Development', Duke Journal of Comparative and International Law, 24, 433-458.

Hoekman, B. and Saggi, K. (2000) 'Assessing the Case for Extending WTO Disciplines on Investment Related Policies', Journal of Economic Integration, 15, 588-610.

Kimmitt, R. and Slaughter, M. (2015) 'How to Make Sure Volvo is Starting a Trend', Wall Street Journal [online], 9 April. Available from: www.wsj.com/articles/how-to-ensure-that-volvo-is-starting-a-trend1428619059 [Accessed 19 February 2016].

McGuire, S. (2014) 'Global Value Chains and State Support in the Aircraft Industry', Business and Politics, 16(4), 615-639.

Moran, T. (2014) Foreign Investment and Supply Chains in Emerging Markets: Recurring Problems and Demonstrated Solutions. Washington D.C.: Petersen Institute for International Studies, PIIE Working Paper 14-12.

OECD (2013) Interconnected Economies: Benefitting from Global Value Chains. Paris: OECD.

Ossa, R. (2015) A Quantitative Analysis of Subsidy Competition in the US. Cambridge, MA: NBER Working Paper 20975.

Sykes, A. (2010) 'The Questionable Case for Subsidies Regulation: a Comparative Perspective', Journal of Legal Analysis, 2, 473-523.

Van Biesebroeck, J. (2009) Bidding for Investment Projects: Smart Public Policy or Corporate Welfare?. Leuven: Centre for Economic Studies.

Van Biesebroeck, J. and Sturgeon, T. (2010) 'Effects of the 2008-09 Crisis on the Automotive Industry in Developing Countries: a Global Value Chain Perspective', in Cattaneo, O., Gereffi, G. and Staritz, C. (eds.), Global Value Chains in a Post-crisis World: a Development Perspective. Washington, DC: World Bank, pp. 209-244.

\section{Author Information}

Bernard Hoekman is Professor and Director, Global Economics at the Robert Schuman Centre for Advanced Studies, European University Institute in Florence, Italy. A CEPR Research Fellow, he is a graduate of the Erasmus University Rotterdam and obtained his PhD in Economics from the University of Michigan. 